\title{
Assessing the Disease-Liability of Mutations in CFTR
}

\author{
Claude Ferec ${ }^{1}$ and Garry R. Cutting ${ }^{2}$ \\ ${ }^{1}$ Faculté de Médecine et des Sciences de la Santé, Université de Bretagne Occidentale; Centre Hospitalier \\ Universitaire (CHU), Hôpital Morvan; INSERM, U1078 Brest, France \\ ${ }^{2}$ McKusick-Nathans Institute of Genetic Medicine, Johns Hopkins University School of Medicine, Baltimore, \\ Maryland 21204 \\ Correspondence: gcutting@jhmi.edu
}

Over 1900 mutations have been reported in the cystic fibrosis transmembrane conductance regulator (CFTR), the gene defective in patients with cystic fibrosis. These mutations have been discovered primarily in individuals who have features consistent with the diagnosis of CF. In some cases, it has been recognized that the mutations are not causative of cystic fibrosis but are responsible for disorders with features similar to $\mathrm{CF}$, and these conditions have been termed CFTR-related disorders or CFTR-RD. There are also mutations in CFTR that do not contribute to any known disease state. Distinguishing CFTR mutations according to their penetrance for an abnormal phenotype is important for clinical management, structure/ function analysis of CFTR, and understanding the molecular and cellular mechanisms underlying CF.

$\mathrm{T}_{\mathrm{n}}^{\mathrm{h}}$ he primary repository for cystic fibrosis transmembrane conductance regulator (CFTR) mutations is a database curated by investigators at the Hospital for Sick Children in Toronto (http://www.genet.sickkids.on.ca/cftr/Home .html). The CF Mutation Database was initiated by Lap-Chee Tsui soon after the cloning of the CFTR gene in 1989. In addition to cataloging DNAvariation in CFTR, each entry includes the predicted effect of a mutation on gene function. Eighty-two percent of the $\sim 1900$ reported mutations in the CF Mutation Database have putative deleterious effects, whereas $14 \%$ appear to be sequence variants of no functional consequence, and the remaining $4 \%$ are of unknown effect.
The vast majority of mutations (97.5\%) reported in CFTR involves one or a few nucleotides. The remaining mutations (2.5\%) involve a larger number of nucleotides such as deletions of entire exons or multiple exons of the gene. Missense mutations (i.e., those that change an amino acid) account for $40 \%$ of the reported mutations. They are the most common form of mutation involving one or a few nucleotides. Frameshift mutations (i.e., those that alter the reading frame) account for almost $16 \%$, whereas splicing and nonsense mutations account for $12 \%$ and $8.5 \%$, respectively. Mutations involving the insertion or deletion of nucleotides in multiples of three that leave the reading frame intact are uncommon $(\sim 2 \%)$. However, among

Editors: John R. Riordan, Richard C. Boucher, and Paul M. Quinton

Additional Perspectives on Cystic Fibrosis available at www.perspectivesinmedicine.org

Copyright (C) 2012 Cold Spring Harbor Laboratory Press; all rights reserved; doi: 10.1101/cshperspect.a009480

Cite this article as Cold Spring Harb Perspect Med 2012;2:a009480 
these in-frame deletions is p.Phe508del, a deletion of three nucleotides in exon 10 of CFTR that causes the loss of a single phenylalanine residue at codon 508. The F508del mutation is found in $70 \%$ of CF alleles in the Caucasian population (Bobadilla et al. 2002). The commonness of the F508del mutation is the primary reason that $\mathrm{CF}$ is one of the most prevalent lethal autosomal recessive disorders among Caucasians. The remainder of the mutations predicted to be deleterious $(0.8 \%)$ lie within the promoter of the CFTR gene.

Most of the 1900 mutations reported in CFTR have not been experimentally evaluated for their effect on the function of CFTR. Mutations that have a frequency in CF patients exceeding $1 \%$ have been investigated in a variety of expression systems for their effect on the splicing of CFTR RNA or the function of the CFTR protein (Cheng et al. 1990; Gregory et al. 1991; Sheppard et al. 1993). Several dozen other mutations reported in patients have been investigated for their functional effects (e.g., Seibert et al. 1996a, 1997). The functional consequences of the remaining $\sim 1850$ CFTR mutations are unknown. Thus, the disease liability of most of the less common CFTR mutations is uncertain. The problem is further complicated as a number of mutations were reported in patients in whom the diagnosis of cystic fibrosis was not verified.

To rigorously ascertain the disease liability of the less common CFTR mutations, a project entitled Clinical and Functional Translation of CFTR (CFTR2; http://www.cftr2.org/) was initiated in 2009 (Sosnay et al. 2011). The project was supported by the U.S. CF Foundation to elucidate the medical implications of as many CFTR mutations as possible. By 2012, the CFTR2 Project had accrued clinical and CF mutations data on almost 40,000 patients from North America and Europe. Collection was based on data derived from CF Patient Registries and large $\mathrm{CF}$ clinics and, as such, all data were derived from patients diagnosed with CF by a medical professional. From these data, it was recognized that $\sim 160$ mutations account for 96\%-97\% of CF alleles. The CFTR2 Project has created a new website that provides clinical information associated with each of the $160 \mathrm{mu}$ tations when found in trans with a CF-causing mutation (as defined by the American College of Medical Genetics [Watson et al. 2004]). Disease liability of each of the 160 mutations is assessed using clinical, functional, and genetic evidence. The CFTR2 database provides a complement to the mutation repository in Toronto. Over the next few years, the CFTR2 Project will evaluate additional mutations beyond the current panel of $\sim 160$.

\section{DISTRIBUTION WORLDWIDE}

The hallmark of the mutational spectrum in the CFTR gene is the very high frequency of the F508del in the Caucasian population (Cystic Fibrosis Genetic Analysis Consortium 1990). Worldwide, the F508del mutation is responsible for about two-thirds of all CF chromosomes in the Caucasian population. However, mutations like the W1282X (p.Trp1282X) show a higher frequency than F508del in some populations such as Ashkenazi Jews (Abeliovich et al. 1992; Shoshani et al. 1992). In 2002, Bobadilla et al. published a large worldwide analysis of CFTR mutations showing that the F508del frequency varies from $100 \%$ in the Faroe Islands of Denmark to $24.5 \%$ in Turkey, and confirmed the northwest to southeast gradient in the F508del distribution in Europe (European Working Group on CF Genetics 1990; Bobadilla et al. 2002).

Worldwide, only a limited number of mutant alleles display a frequency higher than $1 \%$, as for example the G542X (p.Gly542X), which is common in the Mediterranean area of Europe and Africa, which may be associated with the Phoenician migration around the Mediterranean Sea (Loirat et al. 1997). The G551D (p.Gly551Asp) arose in the Celtic population more recently and is still prevalent in Ireland and Brittany (Scotet et al. 2003b), and the N1303K (p.Asn1303Lys) is also rather frequent in populations from the center of Europe (Osborne et al. 1992). Besides these rather common mutations, which are largely distributed in the Caucasian population, there are also some founder effects of mutated alleles observed 
as, for example, in the Reunion Island, where the Y122X ( p.Tyr122X) mutation displays a frequency of 24\% (Duguépéroux et al. 2004), or the 394delTT (p.Leu88IlefsX22) referred to as a Nordic mutation found in countries bordering the Baltic sea (Schwartz et al. 1994). Another mutation that is common in central and eastern Europe is the deletion of exons 2 and 3 of the CFTR, which is the mark of the Slavic origin of this large deletion (Dork et al. 2000). In North America, the distribution of CFTR mutations reflects European descent (the five more common mutations in the U.S. with a frequency over $1 \%$ are F508del, G542X, G551D, W1282X, and N1303K) (Bobadilla et al. 2002). Racial admixture of CFTR mutations is also apparent. For example, the mutation $3120+1 \mathrm{G} \rightarrow \mathrm{A}$ $(c .2988+1 \mathrm{G} \rightarrow \mathrm{A})$ found in Native Africans with a high prevalence in South Africa is the second most prevalent allele in African-American populations of CF patients (Macek et al. 1997). Precise knowledge of the worldwide distribution of the CFTR mutations has facilitated the implementation of CF newborn screening in most of the countries of Europe and in most of the states in the U.S. and Australia (Farrell et al. 2005).

\section{DIFFERENT CLASSES OF MUTATIONS}

Understanding the effect of a mutation on the function of a gene is an essential step in resolving how a mutation causes disease. Mutations that introduce premature termination codons (PTC) such as frameshift, nonsense, and splicing mutations are expected to be deleterious. Other changes in the coding sequence that change a single amino acid (e.g., substitution) may or may not affect function of the encoded protein. Mutations that permit protein to be expressed invariably require experimental studies to assess their effect on the protein. CFTR is an integral membrane protein with multiple different functional and structural domains. Alteration in residue in one location may have local effects on domain function but consequences on other properties are also possible.

To provide context organizing the functional consequences of CFTR mutation, Welsh and Smith proposed a framework of five major classes of defect (Welsh and Smith 1993). Class I mutations involve changes that alter the stability of RNA. These are primarily mutations that introduce a PTC to the RNA transcript. PTC mutations generally cause the loss of messenger RNA because of nonsense-mediated RNA decay (NMRD) (Frischmeyer and Dietz 1999). Mutations in CFTR including G542X, R553X ( $\mathrm{p} . \operatorname{Arg} 553 \mathrm{X}$ ), and W1282X have been shown to lead to NMRD in primary airway cells (Hamosh et al. 1991, 1992b; Will et al. 1995). There are a few exceptions to the concept that PTC mutations cause NMRD. A notable example is the R1162X ( p.Arg1162X) mutation in which the transcript containing a PTC is stable (Rolfini and Cabrini 1993; Will et al. 1995). Patients homozygous for R1162X showed severe pancreatic exocrine deficiency and variable lung disease severity that overlapped with measures observed in F508del homozygotes (Gasparini et al. 1992). Measurements of CFTR function in vivo in two R1162X homozygotes were similar to those recorded in 74 F508del homozygotes (Stanke et al. 2008). Another exception is the mutation E831X (p.Glu831X) that occurs at the $5^{\prime}$ splice site of exon 14a (Hinzpeter et al. 2010). The mutation alters splicing of CFTR such that three nucleotides encoding the mutant nonsense codon are omitted and a protein is synthesized missing the glutamic acid residue at codon 831. Although the resulting protein is stable, it has reduced function and is associated with CF, albeit a milder pancreatic sufficient form (Hinzpeter et al. 2010). Thus, PTC mutations either cause a loss of the RNA transcript and absence of protein or, in a few rare cases, cause stable RNA transcript but a modified protein that is either degraded or malfunctional. In almost all cases, these functional effects produce a CF phenotype. An important exception is when a PTC occurs in the last exon or the last third of a penultimate exon of a gene. In this situation, the RNA transcript is not recognized by the NMRD mechanism and the transcript is stable (Frischmeyer and Dietz 1999). PTC mutations occur in the last exon of CFTR, which are associated with stable transcript and a CFTR protein that is properly folded and present at the cell membrane. In a few 
cases, the resulting truncated protein is sufficiently functional to ameliorate life-shortening lung disease, although dysfunction is apparent in other organ systems (sweat gland [Mickle et al. 1998] or vas deferens [Claustres et al. 2000]).

Class II mutations cause a defect in biogenesis of CFTR. A prime example is the common mutation F508del in which the loss of a single amino acid leads to misfolding of the protein and redirection to degradative machinery in the cell (Kopito 1999). Lowering the temperature of the cell allows a portion of CFTR-bearing F508del to fold properly, and F508del is an excellent example of a naturally occurring temperature-sensitive mutant in humans (Denning et al. 1992). Mutations elsewhere in the gene that caused loss of stability include missense mutations such as G480C (p.Gly480Cys) and others that affect domain-domain interactions in CFTR such as R1070Q (p.Arg1070Gln) (Smit et al. 1995; Serohijos et al. 2008). The evaluation of mutations that alter protein stability are particularly useful in dissecting the structure of CFTR (Patrick et al. 2012).

Class III and class IV mutations are associated with a production of a CFTR molecule that is properly folded and trafficked to the apical membrane. Class III mutations affect the activation of the protein and a prime example is the G551D mutation that causes CFTR to be resistant to activation, even though normal levels of mutant protein are present at the cell surface (Drumm et al. 1991; Anderson and Welsh 1992; Schwiebert et al. 1995). Class IV mutations alter the conductivity of the chloride channel in CFTR. In some cases, these mutations are intimate to the ion conduction pore of the CFTR channel (Sheppard et al. 1993), whereas others appear to affect conductivity through allosteric mechanisms (Seibert et al. 1996b).

Class V mutations reduce the level of wildtype CFTR that is produced by splicing mutations. Although some wild-type CFTR transcript and protein is produced, the level is insufficiently high to avoid the development of the CF phenotype. A key example is the $3849+10 \mathrm{~kb} \quad(\mathrm{c} .3717+12191 \mathrm{C} \rightarrow \mathrm{T})$ mutation (Highsmith et al. 1994). This mutation activates a cryptic splice site in intron 19 of CFTR that causes mis-splicing of exon 19. However, the canonical splice sites are able to complete with the cryptic site resulting in the production of $5 \%-10 \%$ of wild-type transcript. Analysis of additional "leaky" splice mutations affirmed that $\sim 10 \%$ of the levels of wild-type CFTR transcript are required to escape the pulmonary complications of CF (Highsmith et al. 1997; Kerem et al. 1997).

A variety of other mechanistic defects have been associated with CFTR mutations. These have not been formally incorporated into new classes beyond the original five. These include mutations that change the targeting of CFTR (Guggino and Stanton 2006), others that alter the interaction between CFTR and other proteins such as the epithelial sodium channel (ENaC) (Schreiber et al. 1999) and the outwardly rectifying chloride channel (Fulmer et al. 1995), and mutations that affect the membrane residence of CFTR (Silvis et al. 2003).

Understanding the implications of the mutations on CFTR function is critical for the design of therapeutics for cystic fibrosis. $\mathrm{Mu}$ tations such as F508del that cause misfolding of the protein require therapeutics that resolve the misfolding to some extent so that a fraction of mutant protein can transit the Golgi and be directed to the cell membrane. On the other hand, mutations such as G551D require compounds that can activate a mutant protein that is already at the cell surface in levels comparable to what is seen with a normal protein.

\section{GENOTYPE/PHENOTYPE CORRELATIONS}

The degree of correlation between CFTR genotype and phenotype differs among organ systems (Mickle and Cutting 2000). During the hunt for the CF gene, it was shown that allelic variants of CFTR likely influence the pancreatic status in CF patients. Using markers linked to the CF locus, investigators in Toronto showed the robust association between the markers and pancreatic status (Kerem et al. 1989). On identification of the CFTR gene, it was shown that F508del and several other loss-of-function mutations including G551D and G542X are highly associated with pancreatic insufficiency. Other 
mutations that alter residual CFTR function such as R117H (p.Arg117His) and R347P (p.Arg347Pro) have been associated with the pancreatic sufficiency (Kristidis et al. 1992). The correlation with pancreatic status was confirmed in studies of a large collection of CF patients aggregated from different clinics in North America and Europe (The Cystic Fibrosis Genotype-Phenotype Consortium 1993). Correlation of CFTR genotype with other organ system disease has been more subtle. As patients with pancreatic sufficiency also have lower sweat chloride, mutations associated with pancreatic sufficiency show a rough correlation with sweat chloride concentration (Wilschanski et al. 1995). After accounting for pancreatic status, correlation with sweat chloride has not been evident. Furthermore, correlation with lung function has been difficult to detect (The Cystic Fibrosis Genotype-Phenotype Consortium 1993). Wellpowered studies that reveal correlations between genotype and pancreatic status and sweat chloride concentrations have not shown correlation with lung function (as measured by the 1-s forced expiratory volume). However, when a sufficiently large number of patients with identical genotypes are found in a single geographic location such as Belgium and in French Canada, a correlation with decline in lung function becomes evident for the A455E (p.Ala455Glu) mutation (Gan et al. 1995; De Braekeleer et al. 1997).

A complementary approach to correlating genotype with phenotype is to aggregate patients according to the functional class of mutation. In general, mutations in class I to III are associated with complete or near complete loss of CFTR function ( $<3 \%$ of wild-type CFTR function) (Welsh and Smith 1993). Mutations in these classes are primarily associated with pancreatic insufficiency, higher rates of pulmonary infection, and higher mortality (Kubesch et al. 1993; Koch et al. 2001; Ahmed et al. 2003; McKone et al. 2003; Green et al. 2010). On the other hand, residual CFTR function tends to be higher $(3 \%-10 \%)$ in class IV and V mutations. Consequently, patients with these mutations tend to have higher rates of pancreatic sufficiency and less elevated sweat chloride levels (Koch et al. 2001; Ahmed et al. 2003; McKone et al. 2003; Green et al. 2010). As residual CFTR function is increased, such as in the case of the $\mathrm{R} 117 \mathrm{H}$ mutation bearing the 7T variant, lung function is improved sufficiently such that a CF diagnosis may not be evident. Males bearing the combination of F508del mutation panel with R117H-7T are generally discovered because of infertility caused by absence of the vas deferens (see below). These men can have normal lung function (Colin et al. 1996), but some manifest pulmonary disease observed in patients with CF (Castellani et al. 1999).

Classifying mutations according to a single functional effect is problematic as a number of mutations alter several CFTR properties such as folding (class II) and ion conduction (class IV) (Champigny et al. 1995; Sheppard et al. 1995). Furthermore, there appears to be finer gradations of dysfunction among patients with pancreatic insufficiency. Meconium ileus (MI), an obstruction of the intestine at the ileo-colic junction at birth, affects $\sim 15 \%$ of CF patients. MI occurs almost exclusively in patients with pancreatic insufficiency (PI-CF); however, the rate of MI can differ by CFTR genotype. PI-CF patients bearing nonsense mutation G542X have shown the highest rate of MI, whereas those with F508del have an intermediate rate, and patients with the G551D mutation have a relatively low rate of MI (Hamosh et al. 1992a; Kristidis et al. 1992; Feingold and Guilloud-Bataille 1999).

One of the reasons that correlations among organ systems may vary is because of the presence of environmental and genetic modifiers. It was noted shortly after the cloning of CFTR that individuals homozygous for the common mutation F508del had a wide range of lung function (Kerem et al. 1990). This indicated that other factors such as modifier genes and environmental exposures must contribute to variation in patients with identical CFTR genotypes. The analysis of twins and siblings with cystic fibrosis confirmed that the genetic factors contributed substantially to variation of lung function (Mekus et al. 2000; Vanscoy et al. 2007). Studies of twins as they transit to different environments revealed that nongenetic (environmental and stochastic) factors contribute about 
equally to variation in lung function (Collaco et al. 2010). Among nongenetic factors, unique exposures accounted for $2 / 3$ of the variability, whereas shared environment (i.e., living in the same home) accounted for the remaining third. These studies indicate that correlations between CFTR genotype and phenotype can be confounded by the differences in both genetic and nongenetic modifiers among patients. The effect of these confounders will likely differ among different samples of CF patients. One approach to address confounding by modifiers is to study large numbers of patients with different CFTR genotypes to tease out correlations conferred by different CFTR mutations. The CFTR2 project has a large collection of patients to enable this type of study. Indeed, functional studies, performed on over 50 different missense mutations found in at least nine patients in the CFTR2 database, revealed a correlation between CFTR genotype and both sweat chloride concentration and lung function.

\section{CFTR-RELATED DISORDERS}

After the discovery of the CFTR gene, it became evident that dysfunction of CFTR in a single organ could be associated with clinical phenotypes distinct from cystic fibrosis. This is illustrated in the paper by Dumur et al. (1990) who reported the presence of the F508del in 9/17 infertile males because of congenital bilateral absence of vas deferens (CBAVD). A role for CFTR in male infertility was extended by Anguiano et al. who provided evidence of compound heterozygosity for CFTR mutations (i.e., F508del and R117H) in CBAVD patients (Anguiano et al. 1992). Other groups confirmed the presence of two CFTR mutations in a subset of males with CBAVD (De Braekeleer and Ferec 1996; Wilschanski et al. 1996). However, the distribution of CFTR mutations differed between those with CF and those with CBAVD (Dörk et al. 1997; Claustres et al. 2000). The most frequent is a poly $\mathrm{T}$ tract polymorphism located in intron 8 (namely, the IVS8-5T) in the noncoding sequence of the gene, which is an exon 9 splice variant (Chillón et al. 1995). The poly T sequence had been studied by Chu et al. (1993) who have showed an inverse relationship between the length of the polythymidine tract and the proportion of exon 9-CFTR mRNA transcripts. The second one is a complex haplotype with the $\mathrm{R} 117 \mathrm{H}$ missense mutation in exon 7 associated in cis with the IVS8-7T (Kiesewetter et al. 1993; Mercier et al. 1995; Cuppens et al. 1998). This was the beginning of a long debate and discussion in the community on the frontier between $\mathrm{CF}$ and CFTR-related disorders (CFTR-RD).

The criteria for the diagnosis of CF proposed by Rosenstein and Cutting (1998) was widely accepted worldwide and slightly modified by Farrell et al. (2008) more recently with the introduction of neonatal screening for CF. However, it was important to distinguish patients who do not meet the diagnosis criteria for CF but for whom there was evidence of CFTR dysfunction and finally, recently, the term CFTR-related disorders (CFTR-RD) has been accepted by the community (Bombieri et al. 2011). A CFTR-RD is defined as a clinical entity associated with CFTR dysfunction that does not fulfill the diagnostic criteria for CF. Three main entities illustrate this phenotype: congenital bilateral absence of the vas deferens with CFTR dysfunction, acute or recurrent chronic pancreatitis with CFTR dysfunction, and disseminated bronchiectasis associated with CFTR dysfunction.

\section{CFTR Mutations Associated with CBAVD}

Congenital bilateral absence of vas deferens is the most common cause of male sterility in otherwise healthy males with an incidence of about 1:1000 males (Holsclaw et al. 1971; Mak and Jarvi 1996). Many reports from different countries have identified that the disorder is associated with mutations in the CFTR gene, and the development of new technologies allowing the scanning and the rapid sequencing of the coding sequence of the gene shows that CBAVD patients are carrying in about $80 \%$ of cases two mutated alleles in the CFTR gene (Jarvi et al. 1998; Claustres et al. 2000). But it is also widely accepted that CF and CBAVD have complete separate clinical and prognostic characteristics and CBAVD is now considered as the paradigm of CFTR-RD. 
As previously shown in this work, genotype/phenotype studies have clearly identified two categories of CF-causing disease mutations, severe mutations (with no functional CFTR protein) belonging to classes I-III, and mild mutations (more likely to have enough residual CFTR activity to sustain pancreatic function) and belonging to classes IV-V. The classical genotype found in CBAVD patients correspond to the association of a CF-causing mutation in trans with a mutated allele, which is generally a missense variation different from classical CFTR mild mutations. This has led us to the creation of a third group of CFTR mutations termed CFTR-RD alleles. The two most common CFTR-RD alleles are the IVS8-5T, a poly $\mathrm{T}$ tract in intron 8 of the CFTR, and the $\mathrm{R} 117 \mathrm{H}$ associated with the 7T tract (Chillón et al. 1995). The IVS8-5T allele, which is present on at least $5 \%$ of "normal CFTR genes," is the most frequent CFTR-RD allele worldwide (Bombieri et al. 2011). Its frequency in CBAVD males is $5-8$ times higher than in the general population (Chillón et al. 1995; Zielenski et al. 1995). About $35 \%$ of CBAVD males of European descent have inherited a common CF mutation in one gene and the IVS8-5T allele on the other chromosome. The IVS8 poly tract of $\mathrm{T}$ is also a genetic modifier of the $\mathrm{R} 117 \mathrm{H}$ when associated in cis. The combination of $\mathrm{R} 117 \mathrm{H}-7 \mathrm{~T}$ is found in CBAVD, but $\mathrm{R} 117 \mathrm{H}$ associated in cis with a $5 \mathrm{~T}$ is a complex CF allele generally associated with a mild phenotype of CF (Kiesewetter et al. 1993).

The IVS8-5T is considered as a CBAVD mutation with incomplete penetrance. The polymorphic dinucleotide repeat IVS8-TG lying immediately upstream of the IVS8-TG tract was also found to influence exon 9 splicing (Cuppens et al. 1998). The longer the IVS8TGn and the shorter the IVS8-Tn repeats, the greater is exon 9 skipping, leading to reduced levels of CFTR RNA transcript (Niksic et al. 1999; Hefferon et al. 2004). Consequently, CBAVD is more likely to occur in males carrying IVS8-5T and longer IVS8-Tn repeats of 12 or 13 (TG12 TG13) (Groman et al. 2004).

The vast majority of CFTR-RD mutations found in CBAVD patients are not present in mutation screening tests, as commercially avail- able mutation-screening kits only identify the most common CF-causing mutations. Thus, the identification of CFTR-RD mutations require a full exploration of coding/flanking CFTR sequences by scanning (DHPLC or HRM techniques) and sequencing methods (Audrezet et al. 2008). Using these methods, it is possible to identify $85 \%$ of patients harboring two mutations, one of those two being a CFTR-RD mutation (Claustres et al. 2000).

\section{CFTR Mutations in Idiopathic Chronic Pancreatitis}

In the human exocrine pancreas, CFTR is predominantly expressed at the apical membrane of the ductal and centroacinar cells that line the small pancreatic ducts and controls cAMPstimulated $\mathrm{HCO} 3$ secretion into the duct lumen. The major effect of CFTR in pancreatic ducts is to dilute and alkalinize the proteinrich acinar secretions thereby preventing the formation of protein plugs that predispose to pancreatic injury (Park et al. 2010).

In 1998, two groups simultaneously reported an association between CFTR mutations and idiopathic chronic pancreatitis (ICP) (Cohn et al. 1998; Sharer et al. 1998). Until that time, most published studies had only analyzed the most common CF-causing mutations and combined data from these earlier studies indicated that $18 \%$ of subjects with ICP had common CF-causing mutations, whereas $2 \%$ were compound heterozygotes (Audrezet et al. 2002). Subsequent studies analyzing all of the CFTR coding sequence corroborated the early findings and, moreover, showed that about $30 \%$ of ICP patients are carrying at least one CF mutation, and among those $10 \%$ are compound heterozygote, with a CF-causing mutation and in trans a CFTR-RD mutated allele (Audrezet et al. 2002). These studies showed that the risk of ICP increases 6.3 times with a CF-causing mutation and 37 times with a CF-causing mutation plus a milder allele in trans (Cohn 2005; Cohn et al. 2005).

Besides the association of CFTR alleles and ICP, mutations in PRSS1 and in its inhibitor SPINK1 have been correlated with hereditary 
pancreatitis (Whitcomb et al. 1996; Witt et al. 2000). These studies have paved the way to the identification of hereditary pancreatitis diseasecausing mutations as well as susceptibility factors, the most common being the N34S located in SPINK1 (Chen et al. 1999). SPINK1 encodes a serine peptidase inhibitor (kazal type 1). Gene-gene interactions have been documented in individuals who inherit both low penetrance SPINK1 variations and CFTR mutations in ICP. A total of $4 \%$ of ICP patients are trans-heterozygotes of SPINK1/CFTR mutations (Audrezet et al. 2002). Whether the coinheritance of SPINK1 and CFTR variants/mutations is a bona fide example of digenic inheritance or interaction between a disease-causing gene and a genetic modifier is unclear in most cases (Chen 2009).

\section{CFTR Mutations and Disseminated Bronchiectasis}

Disseminated bronchiectasis (DB) is the third documented CFTR-related disorder. DB is a pathological description of lung disease characterized by an abnormal and irreversible dilatation of thick-walled bronchi. Affected areas are inflamed and easily collapsible resulting in air flow obstruction and impaired clearance of secretions (Pasteur et al. 2000).

An increased incidence of CFTR mutation has been found in bronchiectasis and at least one CFTR mutation was reported in $10 \%-50 \%$ of a series of patients in different studies (Girodon et al. 1997; Bombieri et al. 1998; Casals et al. 2004; King et al. 2004). Often in these patients, only one mutation is CF-causing and no particular mutations have been associated only with bronchiectasis. IVS8-5T has been observed at higher than normal frequency in patients with bronchiectasis, but the frequency is not as high as observed in patients with CBAVD. The frequency and nature of CFTR gene mutations reported in bronchiectasis patients differs considerably among publications. This is likely caused by the more heterogeneous nature of bronchiectasis with respect to the other CFTR-RD and also possibly how exhaustive the search was for mutations in the CFTR gene. At the moment, CFTR gene mutation screening is mostly performed for research purposes and it is not generally advisable that it be used for bronchiectasis screening, but rather for CF exclusion.

\section{DIAGNOSIS BASED ON THE KNOWLEDGE OF CFTR MUTATIONS}

To date, more than 1900 mutations have been identified in the CFTR gene and the list is probably incomplete. CFTR mutations vary in their frequency and distribution all over the world in the Caucasian population. Extraordinary improvements in molecular analysis techniques enable the development of high sensitivity mutation panels for most populations and ethnic groups that can routinely be used for diagnosis applications. Among those applications are prenatal diagnosis, newborn screening, as well as cascade screening in affected families. All are based on the precise knowledge of the mutations in the CFTR gene.

\section{Prenatal Diagnosis of CF}

Prenatal diagnosis (PD) is today offered to couples whose offspring have a one-in-four risk of CF, by directly analyzing in the fetus CFTR mutations previously identified in both parents. PD is carried out from chorionic villus sampling extracted at 10-12 weeks of gestation or from amniotic fluid at 16-17 weeks of gestation. In addition to the parents of an already affected child, PD is offered to one-in-four risk couples who have been identified through cascade screening in families, or following the detection of an echogenic bowel on ultrasound examinations during the pregnancy (Scotet et al. 2000, 2002, 2008).

The reproductive decision making of CF couples varies largely among countries. For example, in Brittany, an 18-year experience of prenatal diagnosis of CF was recently reported, and although the life expectancy of patients with CF has considerably improved, the great majority of couples chose pregnancy termination when PD indicated that the fetus had CF (95.9\%) (Scotet et al. 2003a, 2008). The situation is similar in Australia where Sawyer et al. (2006) ana- 
lyzed the reproductive attitudes of a cohort of parents with a CF child and $82 \%$ of those couples declared they would use PD in a subsequent pregnancy. The situation is different in the U.S., where parents of CF children choose PD only for only $20 \%-25 \%$ of subsequent pregnancies (Mischler et al. 1998).

\section{Newborn Screening for CF}

Newborn screening (NBS) for CF has been largely implemented in Australia and in many countries in Europe and, more recently, in most of the states in the U.S. (Comeau et al. 2004). Improvement in outcome for CF patients diagnosed by newborn screening (as opposed to diagnosis based on symptoms) is not as clearly beneficial as for other conditions, such as phenylketonuria. However, the general consensus in Europe and in the U.S. is that there is sufficient evidence to support NBS for CF (Farrell et al. 2005). NBS for CF is based on elevated levels of immunoreactive trypsinogen in the blood of the newborn. Trypsinogen is present at high levels in the CF newborn because of pancreatic exocrine disease. As the screening test is not specific for CF, most NBS programs perform DNA testing to identify known CFTR gene mutations; this strategy is called IRT/DNA strategy (Farrell et al. 2008). The sensitivity of the IRT test coupled with a highly specific test utilizing a panel of the most common CF-causing mutations provides a two-tier test with excellent sensitivity and specificity (Scotet et al. 2000; Castellani et al. 2009). NBS for CF is the first example of the successful introduction of a panel of mutations in a screening test for a hereditary disease.

\section{CONCLUDING REMARKS}

A tremendous amount of information about the mutations in CFTR has been accumulated since the discovery of the gene 23 years ago. Although the challenge of curing the disease remains, knowledge of the genetic basis of CF provided immense insight into the pathophysiology of the disease. In addition, identification and characterization of the mutations in CFTR has aided the diagnosis of CF, facilitated ge- netic counseling for families, and screening of newborns and carriers in the general population. Last but not least, it becomes more evident that the precise knowledge of the CFTR mutations will be a prerequisite for the rationale basis for mutation-specific therapies that are now imminent (Accurso et al. 2010).

\section{ACKNOWLEDGMENTS}

This work is supported by grants from the National Institutes of Health (NIDDK DK44003 to G.R.C.) and the Cystic Fibrosis Foundation (CFF-CUTTIN08A0, 09A0 and 11A0 to G.R.C.).

\section{REFERENCES}

Abeliovich D, Lavon IP, Lerer I, Cohen T, Springer C, Avital A, Cutting GR. 1992. Screening for five mutations detects $97 \%$ of cystic fibrosis (CF) chromosomes and predicts a carrier frequency of 1:29 in the Jewish Ashkenazi population. Am J Hum Genet 51: 951-956.

Accurso FJ, Rowe SM, Clancy JP, Boyle MP, Dunitz JM, Durie PR, Sagel SD, Hornick DB, Konstan MW, Donaldson SH, et al. 2010. Effect of VX-770 in persons with cystic fibrosis and the G551D-CFTR mutation. $N$ Engl J Med 363: 1991-2003.

Ahmed N, Corey M, Forstner G, Zielenski J, Tsui LC, Ellis L, Tullis E, Durie P. 2003. Molecular consequences of cystic fibrosis transmembrane regulator (CFTR) gene mutations in the exocrine pancreas. Gut 52: 1159-1164.

Anderson MP, Welsh MJ. 1992. Regulation by ATP and ADP of CFTR chloride channels that contain mutant nucleotide-binding domains. Science 257: 1701-1704.

Anguiano A, Oates RD, Amos JA, Dean M, Gerrard B, Stewart C, Maher TA, White MB, Milunsky A. 1992. Congenital bilateral absence of the vas deferens - a primarily genital form of cystic fibrosis. JAMA 267: 1794-1797.

Audrezet MP, Chen JM, Le Marechal C, Ruszniewski P, Robaszkiewicz M, Raguenes O, Quere I, Scotet V, Ferec C. 2002. Determination of the relative contribution of three genes - the cystic fibrosis transmembrane conductance regulator gene, the cationic trypsinogen gene, and the pancreatic secretory trypsin inhibitor gene-to the etiology of idiopathic chronic pancreatitis. Eur J Hum Genet 10: $100-106$.

Audrezet MP, Dabricot A, Le Marechal C, Ferec C. 2008. Validation of high-resolution DNA melting analysis for mutation scanning of the cystic fibrosis transmembrane conductance regulator (CFTR) gene. J Mol Diagn 10: 424-434.

Bobadilla JL, Macek M, Fine JP, Farrell PM. 2002. Cystic fibrosis: A worldwide analysis of CFTR mutations - correlation with incidence data and application to screening. Hum Mutat 19: 575-606.

Bombieri C, Benetazzo M, Saccomani A, Belpinta F, Gile LS, Luisetti M, Pignatti PF. 1998. Complete mutational 
screening of the CFTR gene in 120 patients with pulmonary disease. Hum Genet 103: 718-722.

Bombieri C, Claustres M, De Boeck K, Derichs N, Dodge J, Girodon E, Sermet I, Schwarz M, Tzetis M, Wilschanski M, et al. 2011. Recommendations for the classification of diseases as CFTR-related disorders. J Cyst Fibros 10: S86-S102.

Casals T, De Gracia J, Gallego M, Dorca J, RodriguezSanchon B, Ramos MD, Gimenez J, Cistero-Bahima A, Olveira C, Estivill X. 2004. Bronchiectasis in adult patients: An expression of heterozygosity for CFTR gene mutations? Clin Genet 65: 490-495.

Castellani C, Bonizzato A, Pradal U, Filicori M, Foresta C, La Sala GB, Mastella G. 1999. Evidence of mild respiratory disease in men with congenital absence of the vas deferens. Respir Med 93: 869-875.

Castellani C, Southern KW, Brownlee K, Dankert RJ, Duff A, Farrell M, Mehta A, Munck A, Pollitt R, SermetGaudelus I, et al. 2009. European best practice guidelines for cystic fibrosis neonatal screening. J Cyst Fibros 8: 153-173.

Champigny G, Imler JL, Puchelle E, Dalemans W, Gribkoff V, Hinnrasky J, Dott K, Barbry P, Pavirani A, Lazdunski M. 1995. A change in gating mode leading to increased intrinsic $\mathrm{Cl}^{-}$channel activity compensates for defective processing in a mild form of the disease. $E M B O J \mathbf{1 4}$ 2417-2423.

Chen JM. 2009. Chronic pancreatitis: Genetics and pathogenesis. Annu Rev Genomics Hum Genet 10: 63-87.

Chen JM, Audrezet MP, Mercier B, Quere I, Ferec C. 1999. Exclusion of anionic trypsinogen and mesotrypsinogen involvement in hereditary pancreatitis without cationic trypsinogen gene mutations. Scand J Gastroenterol 34: 831-832.

Cheng SH, Gregory RJ, Marshall J, Paul S, Souza DW, White GA, O’Riordan CR, Smith AE. 1990. Defective intracellular transport and processing of CFTR is the molecular basis of most cystic fibrosis. Cell 63: 827-834.

Chillón M, Casals T, Mercier B, Bassas L, Lissens W, Silber S, Romey MC, Ruiz-Romero BS, Verlingue C, Claustres M, et al. 1995. Mutations in the cystic fibrosis gene in patients with congenital absence of the vas deferens. N Engl J Med 332: 1475-1480.

Chu CS, Trapnell BC, Curristin S, Cutting GR, Crystal RG. 1993. Genetic basis of variable exon 9 skipping in cystic fibrosis transmembrane conductance regulator mRNA. Nat Genet 3: 151-156.

Claustres M, Guittard C, Bozon D, Chevalier F, Verlingue C, Ferec C, Girodon E, Cazeneuve C, Bienvenu T, Lalau G, et al. 2000. Spectrum of CFTR mutations in cystic fibrosis and in congenital absence of the vas deferens in France. Hum Mutat 16: 143-156.

Cohn JA. 2005. Reduced CFTR function and the pathobiology of idiopathic pancreatitis. J Clin Gastroenterol 39: S70-S77.

Cohn JA, Friedman KJ, Noone PG, Knowles MR, Silverman LM, Jowell PS. 1998. Relation between mutations of the cystic fibrosis gene and idiopathic pancreatitis. $N$ Engl J Med 339: 653-658.

Cohn JA, Neoptolemos JP, Feng J, Yan J, Jiang Z, Greenhalf W, McFaul C, Mountford R, Sommer SS. 2005. In- creased risk of idiopathic chronic pancreatitis in cystic fibrosis carriers. Hum Mutat 26: 303-307.

Colin AA, Sawyer SM, Mickle JE, Oates RD, Milunsky A, Amos JA. 1996. Pulmonary function and clinical observations in men with congenital bilateral absence of the vas deferens. Chest 110: 440-445.

Collaco JM, Blackman SM, McGready J, Naughton KM, Cutting GR. 2010. Quantification of the relative contribution of environmental and genetic factors to variation in cystic fibrosis lung function. J Pediatr 157: 802-807.

Comeau AM, Parad RB, Dorkin HL, Dovey M, Gerstle R, Haver K, Lapey A, O'Sullivan BP, Waltz DA, Zwerdling RG, et al. 2004. Population-based newborn screening for genetic disorders when multiple mutation DNA testing is incorporated: A cystic fibrosis newborn screening model demonstrating increased sensitivity but more carrier detections. Pediatrics 113: 1573-1581.

Cuppens H, Lin W, Jaspers M, Costes B, Teng H, Vankeerberghen A, Jorissen M, Droogmans G, Reynaert I, Goossens M, et al. 1998. Polyvariant mutant cystic fibrosis transmembrane conductance regulator genes: The polymorphic (TG)m locus explains the partial penetrance of the 5T polymorphism as a disease mutation. J Clin Invest 101: $487-496$.

Cystic Fibrosis Genetic Analysis Consortium. 1990. Worldwide survey of the $\delta$ F508 mutation-Report from the Cystic Fibrosis Genetic Analysis Consortium (CFGAC). Am J Hum Genet 47: 354-359.

De Braekeleer M, Ferec C. 1996. Mutations in the cystic fibrosis gene in men with congenital bilateral absence of the vas deferens. Mol Hum Reprod 2: 677.

De Braekeleer M, Allard C, Leblanc JP, Simard F, Aubin G. 1997. Genotype-phenotype correlation in cystic fibrosis patients compound heterozygous for the A455E mutation. Hum Genet 101: 208-211.

Denning GM, Anderson MP, Amara JF, Marshall J, Smith AE, Welsh MJ. 1992. Processing of mutant cystic fibrosis transmembrane conductance regulator is temperature-sensitive. Nature 358: 761-764.

Dörk T, Dworniczak B, Aulehia-Scholz C, Wieczorek D, Böhm I, Mayerova A, Seydewitz H, Nieschlag E, Meschede D, Horst J, et al. 1997. Distinct spectrum of CFTR gene mutations in congenital absence of vas deferens. Hum Genet 100: 367-377.

Dörk T, Macek M Jr, Mekus F, Tummler B, Tzountzouris J, Casals T, Krebsova A, Koudova M, Sakmaryova I, Macek M Sr, et al. 2000. Characterization of a novel 21-kb deletion, CFTRdele2,3(21 kb), in the CFTR gene: A cystic fibrosis mutation of Slavic origin common in Central and East Europe. Hum Genet 106: 259-268.

Drumm ML, Wilkinson DJ, Smit LS, Worrell RT, Strong TV, Frizzell RA, Dawson DC, Collins FS. 1991. Chloride conductance expressed by $\delta$ F508 and other mutant CFTRs in Xenopus oocytes. Science 254: 1797-1799.

Dugueperoux I, Bellis G, Lesure JF, Renouil M, Flodrops H, De Braekeleer M. 2004. Cystic fibrosis at the Reunion Island (France): Spectrum of mutations and genotypephenotype for the Y122X mutation. J Cyst Fibros 3: $185-188$.

Dumur V, Gervais R, Rigot JM, Lafitte JJ, Manouvrier S, Biserte J, Mazeman E, Roussel P. 1990. Abnormal distribution of CF $\delta$ F508 allele in azoospermic men with 
congenital aplasia of epididymis and vas deferens [letter] Lancet 336: 512.

European Working Group on CF Genetics. 1990. Gradient of distribution in Europe of the major CF mutation and of its associated haplotype. Hum Genet 85: 436-445.

Farrell PM, Lai HJ, Kosorok MR, Laxova A, Green CG, Collins J, Hoffman G, Laessig R, Rock MJ, Splaingard ML. 2005. Evidence on improved outcomes with early diagnosis of cystic fibrosis through neonatal screening: Enough is enough! J Pediatr 147: S30-S36.

Farrell PM, Rosenstein BJ, White TB, Accurso FJ, Castellani C, Cutting GR, Durie PR, LeGrys VA, Massie J, Parad RB, et al. 2008. Guidelines for diagnosis of cystic fibrosis in newborns through older adults: Cystic Fibrosis Foundation consensus report. J Pediatr 153: S4-S14.

Feingold J, Guilloud-Bataille M. 1999. Genetic comparisons of patients with cystic fibrosis with or without meconium ileus. Clinical Centers of the French CF Registry. Ann Genet 42: 147-150.

Frischmeyer PA, Dietz HC. 1999. Nonsense-mediated mRNA decay in health and disease. Hum Mol Genet 8: 1893-1900.

Fulmer SB, Schwiebert EM, Morales MM, Guggino WB, Cutting GR. 1995. Two cystic fibrosis transmembrane conductance regulator mutations have different effects on both pulmonary phenotype and regulation of outwardly rectified chloride currents. Proc Natl Acad Sci 92: 6832-6836.

Gan KH, Veeze HJ, van den Ouweland AMW, Halley DJJ, Scheffer H, Van Der Hout A, Overbeek SE, deJongste JC, Bakker W, Heijerman HGM. 1995. A cystic fibrosis mutation associated with mild lung disease. $N$ Engl J Med 333: 95-99.

Gasparini P, Borgo G, Mastella G, Bonizzato A, Dognini M, Pignatti PF. 1992. Nine cystic fibrosis patients homozygous for the CFTR nonsense mutation R1162X have mild or moderate lung disease. J Med Genet 29: 558-562.

Girodon E, Cazaneuve C, Lebargy F, Chinet TC, Costes B, Ghanem N, Martin J, Lemay S, Scheid P, Housset B, et al. 1997. CFTR gene mutations in adults with disseminated bronchiectasis. Eur J Hum Genet 5: 149-155.

Green DM, McDougal KE, Blackman SM, Sosnay PR, Henderson LB, Naughton KM, Collaco JM, Cutting GR. 2010. Mutations that permit residual CFTR function delay acquisition of multiple respiratory pathogens in CF patients. Respir Res 11: 140.

Gregory RJ, Rich DP, Cheng SH, Souza DW, Paul S, Manavalan P, Anderson MP, Welsh MJ, Smith AE. 1991. Maturation and function of cystic fibrosis transmembrane conductance regulator variants bearing mutations in putative nucleotide-binding domains 1 and 2. Mol Cell Biol 11: 3886-3893.

Groman JD, Hefferon TW, Casals T, Bassas L, Estivill X, Des GM, Guittard C, Koudova M, Fallin MD, Nemeth K, et al. 2004. Variation in a repeat sequence determines whether a common variant of the cystic fibrosis transmembrane conductance regulator gene is pathogenic or benign. Am J Hum Genet 74: 176-179.

Guggino WB, Stanton BA. 2006. New insights into cystic fibrosis: Molecular switches that regulate CFTR. Nat Rev Mol Cell Biol 7: 426-436.
Hamosh A, Trapnell BC, Zeitlin PL, Montrose-Rafizadeh C, Rosenstein BJ, Crystal RG, Cutting GR. 1991. Severe deficiency of CFTR mRNA carrying nonsense mutations R553X and W1316X in respiratory epithelial cells of patients with cystic fibrosis. J Clin Invest 88: 1880-1885.

Hamosh A, King TM, Rosenstein BJ, Corey M, Levison H, Durie P, Tsui LC, McIntosh I, Keston M, Brock DJH, et al. 1992a. Cystic fibrosis patients bearing the common missense mutation Gly $\rightarrow$ Asp at codon 551 and the $\delta$ F508 are indistinguishable from $\delta$ F508 homozygotes except for decreased risk of meconium ileus. Am J Hum Genet 51: 245-250.

Hamosh A, Rosenstein BJ, Cutting GR. 1992b. CFTR nonsense mutations G542X and W1282X associated with severe reduction of CFTR mRNA in nasal epithelial cells. Hum Mol Genet 1: 542-544.

Hefferon TW, Groman JD, Yurk CE, Cutting GR. 2004. A variable dinucleotide repeat in the CFTR gene contributes to phenotype diversity by forming RNA secondary structures that alter splicing. Proc Natl Acad Sci 101: 3504-3509.

Highsmith WE Jr, Burch LH, Zhou Z, Olsen JC, Boat TE, Spock A, Gorvoy JD, Quittell L, Friedman KJ, Silverman LM, et al. 1994. A novel mutation in the cystic fibrosis gene in patients with pulmonary disease but normal sweat chloride concentrations. N Engl J Med 331: 974980.

Highsmith WE Jr, Lauranell BH, Zhaoqing Z, Olsen JC, Strong TV, Smith T, Friedman KJ, Silverman LM, Boucher RC, Collins FS, et al. 1997. Identification of a splice site mutation $(2789+5 \mathrm{G} \rightarrow \mathrm{A})$ associated with small amounts of normal CFTR mRNA and mild cystic fibrosis. Hum Mutat 9: 332-338.

Hinzpeter A, Aissat A, Sondo E, Costa C, Arous N, Gameiro C, Martin N, Tarze A, Weiss L, de Becdelievre A, et al. 2010. Alternative splicing at a NAGNAG acceptor site as a novel phenotype modifier. PLoS Genet 6: e1001153.

Holsclaw DS, Perlmutter AD, Jockin H, Shwachman H. 1971. Genital abnormalities in male patients with cystic fibrosis. J Urol 106: 568-574.

Jarvi K, McCallum S, Zielenski J, Durie P, Tullis E, Wilchanski M, Margolis M, Asch M, Ginzburg B, Martin S, et al. 1998. Heterogeneity of reproductive tract abnormalities in men with absence of the vas deferens: Role of cystic fibrosis transmembrane conductance regulator gene mutations. Fertil Steril 70: 724-728.

Kerem BS, Buchanan JA, Durie P, Corey ML, Levison H, Rommens JM, Buchwald M, Tsui LC. 1989. DNA marker haplotype association with pancreatic sufficiency in cystic fibrosis. Am J Hum Genet 44: 827-834.

Kerem E, Corey M, Kerem BS, Rommens J, Markiewicz D, Levison H, Tsui LC, Durie P. 1990. The relation between genotype and phenotype in cystic fibrosis-analysis of the most common mutation ( $\delta$ F508). $N$ Engl J Med 323: $1517-1522$.

Kerem E, Rave-Harel N, Augarten A, Madgar I, NissimRafinia M, Yahav Y, Goshen R, Bentur L, Rivlin J, Aviram M, et al. 1997. A cystic fibrosis transmembrane conductance regulator splice variant with partial penetrance associated with variable cystic fibrosis presentations. Am J Resp Crit Care Med 155: 1914-1920. 
C. Ferec and G.R. Cutting

Kiesewetter S, Macek M Jr, Davis C, Curristin SM, Chu CS, Graham C, Shrimpton AE, Cashman SM, Tsui LC, Mickle J, et al. 1993. A mutation in the cystic fibrosis transmembrane conductance regulator gene produces different phenotypes depending on chromosomal background. Nature Genet 5: 274-278.

King PT, Freezer NJ, Holmes PW, Holdsworth SR, Forshaw K, Sart DD. 2004. Role of CFTR mutations in adult bronchiectasis. Thorax 59: 357-358.

Koch C, Cuppens H, Rainisio M, Madessani U, Harms H, Hodson M, Mastella G, Navarro J, Strandvik B, McKenzie S. 2001. European Epidemiologic Registry of Cystic Fibrosis (ERCF): Comparison of major disease manifestations between patients with different classes of mutations. Pediatr Pulmonol 31: 1-12.

Kopito RR. 1999. Biosynthesis and degradation of CFTR Physiol Rev 79: S167-S173.

Kristidis P, Bozon D, Corey M, Markiewicz D, Rommens J, Tsui LC, Durie P. 1992. Genetic determination of exocrine pancreatic function in cystic fibrosis. Am J Hum Genet 50: 1178-1184.

Kubesch P, Dörk T, Wulbrand U, Kälin N, Neumann T, Wulf B, Geerlings H, Weibbrodt H, von der Hardt $\mathrm{H}$ Tümmler B. 1993. Genetic determinants of airways' colonization with pseudomonas aeruginosa in cystic fibrosis. Lancet 341: 189-193.

Loirat F, Hazout S, Lucotte G. 1997. G542X as a probable Phoenician cystic fibrosis mutation. Hum Biol 69: 419425.

Macek M Jr, Mackova A, Hamosh A, Hilman BC, Selden RF, Lucotte G, Friedman KJ, Knowles MR, Rosenstein BJ, Cutting GR. 1997. Identification of common cystic fibrosis mutations in African-Americans with cystic fibrosis increases the detection rate to 75\%. Am J Hum Genet 60: $1122-1127$.

Mak V, Jarvi K. 1996. The genetics of male infertility. J Urol 156: $1245-1256$

McKone EF, Emerson SS, Edwards KL, Aitken ML. 2003. Effect of genotype on phenotype and mortality in cystic fibrosis: A retrospective cohort study. Lancet 361: 16711676.

Mekus F, Ballmann M, Bronsveld I, Bijman J, Veeze H, Tummler B. 2000. Categories of $\delta F 508$ homozygous cystic fibrosis twin and sibling pairs with distinct phenotypic characteristics. Twin Res 3: 277-293.

Mercier B, Verlingue C, Lissens W, Silber S, Novelli G, Bonduelle M, Audrézet MP, Férec C. 1995. Is congenita bilateral absence of vas deferens a primary form of cystic fibrosis? Analyses of the CFTR gene in 67 patients. Am J Hum Genet 56: 272-277.

Mickle JE, Cutting GR. 2000. Genotype-phenotype relationships in cystic fibrosis. Med Clin North Am 84: 597-607.

Mickle JE, Macek M Jr, Fulmer-Smentek SB, Egan MM, Schwiebert E, Guggino W, Moss R, Cutting GR. 1998. A mutation in the cystic fibrosis transmembrane conductance regulator gene associated with elevated sweat chloride concentrations in the absence of cystic fibrosis. Hum Mol Genet 7: 729-735.

Mischler EH, Wilfond BS, Fost N, Laxova A, Reiser C, Sauer CM, Makholm LM, Shen G, Feenan L, McCarthy C, et al. 1998. Cystic fibrosis newborn screening: Impact on reproductive behavior and implications for genetic counseling. Pediatrics 102: 44-52.

Niksic M, Romano M, Buratti E, Pagani F, Baralle FE. 1999. Functional analysis of cis-acting elements regulating the alternative splicing of human CFTR exon 9. Hum Mol Genet 8: 2339-2349.

Osborne L, Santis G, Schwarz M, Klinger K, Dork T, McIntosh I, Schwartz M, Nunes V, Macek M Jr, Reiss J, et al. 1992. Incidence and expression of the N1303K mutation of the cystic fibrosis (CFTR) gene. Hum Genet 89: $653-$ 658.

Park HW, Nam JH, Kim JY, Namkung W, Yoon JS, Lee JS, Kim KS, Venglovecz V, Gray MA, Kim KH, et al. 2010. Dynamic regulation of CFTR bicarbonate permeability by $\left[\mathrm{Cl}^{-}\right]_{\mathrm{i}}$ and its role in pancreatic bicarbonate secretion. Gastroenterology 139: 620-631.

Pasteur MC, Helliwell SM, Houghton SJ, Webb SC, Foweraker JE, Coulden RA, Flower CD, Bilton D, Keogan MT 2000. An investigation into causative factors in patients with bronchiectasis. Am J Respir Crit Care Med 162: 1277-1284.

Patrick AE, Karamyshev A, Millen L, Thomas PJ. 2012. Alteration of CFTR transmembrane span integration by disease-causing mutations. Mol Biol Cell 22: 4461-4471.

Rolfini R, Cabrini G. 1993. Nonsense mutation R1162X of the cystic fibrosis transmembrane conductance regulator gene does not reduce messenger RNA expression in nasal epithelial tissue. J Clin Invest 92: 2683-2687.

Rosenstein BJ, Cutting GR. 1998. The diagnosis of cystic fibrosis: A consensus statement. J Pediatr 132: 589-595.

Sawyer SM, Cerritelli B, Carter LS, Cooke M, Glazner JA, Massie J. 2006. Changing their minds with time: A comparison of hypothetical and actual reproductive behaviors in parents of children with cystic fibrosis. Pediatrics 118: e649-e656.

Schreiber R, Hopf A, Mall M, Greger R, Kunzelmann K. 1999. The first-nucleotide binding domain of the cystic fibrosis transmembrane conductance regulator is important for inhibition of the epithelial $\mathrm{Na}^{+}$channel. Proc Natl Acad Sci 96: 5310-5315.

Schwartz M, Anvret M, Claustres M, Eiken HG, Eiklid K, Schaedel C, Stolpe L, Tranebjaerg L. 1994. 394delTT: A Nordic cystic fibrosis mutation. Hum Genet 93: 157-161.

Schwiebert EM, Egan ME, Hwang T-H, Fulmer SB, Allen SS, Cutting GR, Guggino WB. 1995. CFTR regulates outwardly rectifying chloride channels through an autocrine mechanism involving ATP. Cell 81: 1-20.

Scotet V, De Braekeleer M, Roussey M, Rault G, Parent P, Dagorne M, Journel H, Lemoigne A, Codet JP, Catheline M, et al. 2000. Neonatal screening for cystic fibrosis in Brittany, France: Assessment of 10 years' experience and impact on prenatal diagnosis. Lancet 356: 789-794.

Scotet V, De Braekeleer M, Audrezet MP, Quere I, Mercier B, Dugueperoux I, Andrieux J, Blayau M, Ferec C. 2002. Prenatal detection of cystic fibrosis by ultrasonography: A retrospective study of more than 346,000 pregnancies. $J$ Med Genet 39: 443-448.

Scotet V, Audrezet MP, Roussey M, Rault G, Blayau M, DeBraekeleer M, Ferec C. 2003a. Impact of public health strategies on the birth prevalence of cystic fibrosis in Brittany, France. Hum Genet 113: 280-285. 
Scotet V, Barton DE, Watson JB, Audrezet MP, McDevitt T, McQuaid S, Shortt C, De Braekeleer M, Ferec C, Le Marechal C. 2003b. Comparison of the CFTR mutation spectrum in three cohorts of patients of Celtic origin from Brittany (France) and Ireland. Hum Mutat 22: 105.

Scotet V, Dugueperoux I, Audrezet MP, Blayau M, Boisseau P, Journel H, Parent P, Ferec C. 2008. Prenatal diagnosis of cystic fibrosis: The 18-year experience of Brittanny (western France). Prenat Diagn 28: 197-202.

Seibert FS, Linsdell P, Loo TW, Hanrahan JW, Clarke DM, Riordan JR. 1996a. Disease-associated mutations in the fourth cytoplasmic loop of cystic fibrosis transmembrane conductance regulator compromise biosynthetic processing and chloride channel activity. J Biol Chem 271: $15139-15145$.

Seibert FS, Linsdell P, Loo TW, Hanrahan JW, Riordan JR, Clarke DM. 1996b. Cytoplasmic loop three of cystic fibrosis transmembrane conductance regulator contributes to regulation of chloride channel activity. J Biol Chem 271: 27493-27499.

Seibert FS, Jia Y, Mathews CJ, Hanrahan JW, Riordan JR, Loo TW, Clarke DM. 1997. Disease-associated mutations in cytoplasmic loops 1 and 2 of cystic fibrosis transmembrane conductance regulator impede processing or opening of the channel. Biochemistry 36: 11966-11974.

Serohijos AW, Hegedus T, Aleksandrov AA, He L, Cui L, Dokholyan NV, Riordan JR. 2008. Phenylalanine-508 mediates a cytoplasmic-membrane domain contact in the CFTR 3D structure crucial to assembly and channel function. Proc Natl Acad Sci 105: 3256-3261.

Sharer N, Schwarz M, Malone G, Howarth A, Painter J, Super M, Braganza J. 1998. Mutations of the cystic fibrosis gene in patients with chronic pancreatitis. $N$ Engl Med 339: 645-652.

Sheppard DN, Rich DP, Ostedgaard LS, Gregory RJ, Smith AE, Welsh MJ. 1993. Mutations in CFTR associated with mild-disease-form $\mathrm{Cl}^{-}$channels with altered pore properties. Nature 362: 160-164.

Sheppard DN, Ostedgaard LS, Winter MC, Welsh MJ. 1995. Mechanism of dysfunction of two nucleotide binding domain mutations in cystic fibrosis transmembrane conductance regulator that are associated with pancreatic sufficiency. EMBO J 14: 876-883.

Shoshani T, Augarten A, Gazit E, Bashan N, Yahav Y, Rivlin Y, Tal A, Seret H, Yaar L, Kerem E, et al. 1992. Association of a nonsense mutation (W1282X), the most common mutation in the Ashkenazi Jewish cystic fibrosis patients in Israel, with severe disease presentation. Am J Hum Genet 50: $222-228$.

Silvis MR, Picciano JA, Bertrand C, Weixel K, Bridges RJ, Bradbury NA. 2003. A mutation in the cystic fibrosis transmembrane conductance regulator generates a novel internalization sequence and enhances endocytic rates. J Biol Chem 278: 11554-11560.

Smit LS, Strong TV, Wilkinson DJ, Macek M Jr, Mansoura MK, Wood DL, Cole JL, Cutting GR, Cohn JA, Dawson DC, et al. 1995. Missense mutation (G480C) in the CFTR gene associated with protein mislocalization but normal chloride channel activity. Hum Mol Genet 4: 269-273.

Sosnay PR, Castellani C, Corey M, Dorfman R, Zielenski J, Karchin R, Penland CM, Cutting GR. 2011. Evaluation of the disease liability of CFTR variants. Methods Mol Biol 742: $355-372$.

Stanke F, Ballmann M, Bronsveld I, Dork T, Gallati S, Laabs U, Derichs N, Ritzka M, Posselt HG, Harms HK, et al. 2008. Diversity of the basic defect of homozygous CFTR mutation genotypes in humans. J Med Genet 45: 47-54.

The Cystic Fibrosis Genotype-Phenotype Consortium. 1993. Correlation between genotype and phenotype in patients with cystic fibrosis. N Engl J Med 329: 1308.

Vanscoy LL, Blackman SM, Collaco JM, Bowers A, Lai T, Naughton K, Algire M, McWilliams R, Beck S, HooverFong J, et al. 2007. Heritability of lung disease severity in cystic fibrosis. Am J Respir Crit Care Med 175: 10361043.

Watson MS, Cutting GR, Desnick RJ, Driscoll DA, Klinger K, Mennuti M, Palomaki GE, Popovich BW, Pratt VM, Rohlfs EM, et al. 2004. Cystic fibrosis population carrier screening: 2004 revision of American College of Medical Genetics mutation panel. Genet Med 6: 387-391.

Welsh MJ, Smith AE. 1993. Molecular mechanisms of CFTR chloride channel dysfunction in cystic fibrosis. Cell 73: $1251-1254$.

Whitcomb DC, Gorry MC, Preston RA, Furey W, Sossenheimer MJ, Ulrich CD, Martin SP, Gates LJ Jr, Amann ST, Toskes PP, et al. 1996. Hereditary pancreatitis is caused by a mutation in the cationic trypsinogen gene. Nat Genet 14: $141-145$.

Will K, Dörk T, Stuhrmann M, von der Hardt H, Ellemunter H, Tümmler B, Schmidtke J. 1995. Transcript analysis of CFTR nonsense mutations in lymphocytes and nasal epithelial cells from cystic fibrosis patients. Hum Mutat 5: 210-220.

Wilschanski M, Zielenski J, Markiewicz D, Tsui LC, Corey M, Levison H, Durie PR. 1995. Correlation of sweat chloride concentration with classes of the cystic fibrosis transmembrane conductance regulator gene mutations. J Pediatr 127: 705-710.

Wilschanski M, Corey M, Durie P, Tullis E, Bain J, Asch M, Ginzburg B, Jarvi K, Buckspan M, Hartwick W. 1996. Diversity of reproductive tract abnormalities in men with cystic fibrosis. JAMA 276: 607-608.

Witt H, Luck W, Hennies HDC, Classen M, Kage A, Lass U, Landt O, Becker M. 2000. Mutations in the gene encoding the serine protease inhibitor, Kazal Type 1 are associated with chronic pancreatitis. Nat Genet 25: 213-216.

Zielenski J, Patrizio P, Corey M, Handelin B, Markiewicz D, Asch R, Tsui LC. 1995. CFTR gene variant for patients with congenital absence of vas deferens. Am J Hum Genet 57: $958-960$. 


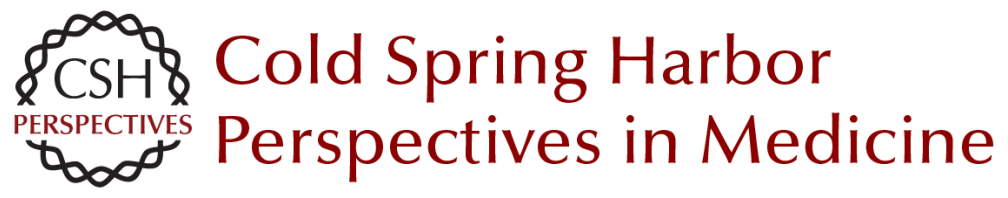

\section{Assessing the Disease-Liability of Mutations in CFTR}

Claude Ferec and Garry R. Cutting

Cold Spring Harb Perspect Med 2012; doi: 10.1101/cshperspect.a009480

Subject Collection Cystic Fibrosis

Antibiotic and Anti-Inflammatory Therapies for

Cystic Fibrosis

James F. Chmiel, Michael W. Konstan and J. Stuart Elborn

Structure and Function of the Mucus Clearance System of the Lung

Brenda M. Button and Brian Button

New Pulmonary Therapies Directed at Targets

Other than CFTR

Scott H. Donaldson and Luis Galietta

The Cystic Fibrosis Airway Microbiome

Susan V. Lynch and Kenneth D. Bruce

\section{Cystic Fibrosis Transmembrane Conductance \\ Regulator (ABCC7) Structure \\ John F. Hunt, Chi Wang and Robert C. Ford}

Status of Fluid and Electrolyte Absorption in

Cystic Fibrosis

M.M. Reddy and M. Jackson Stutts

The Influence of Genetics on Cystic Fibrosis

Phenotypes

Michael R. Knowles and Mitchell Drumm

Perspectives on Mucus Properties and Formation

--Lessons from the Biochemical World

Daniel Ambort, Malin E.V. Johansson, Jenny K.

Gustafsson, et al.
The Cystic Fibrosis Intestine

Robert C. De Lisle and Drucy Borowitz

Cystic Fibrosis Transmembrane Regulator

Correctors and Potentiators

Steven M. Rowe and Alan S. Verkman

The Cystic Fibrosis of Exocrine Pancreas

Michael Wilschanski and Ivana Novak

Dynamics Intrinsic to Cystic Fibrosis Transmembrane Conductance Regulator Function and Stability

P. Andrew Chong, Pradeep Kota, Nikolay V.

Dokholyan, et al.

The Cystic Fibrosis Gene: A Molecular Genetic

Perspective

Lap-Chee Tsui and Ruslan Dorfman

The CFTR Ion Channel: Gating, Regulation, and

Anion Permeation

Tzyh-Chang Hwang and Kevin L. Kirk

Assessing the Disease-Liability of Mutations in CFTR

Claude Ferec and Garry R. Cutting

Supramolecular Dynamics of Mucus Pedro Verdugo

For additional articles in this collection, see http://perspectivesinmedicine.cshlp.org/cgi/collection/ 